\title{
The Transformative Potential of Indigenous-Driven Approaches to Implementing Free, Prior and Informed Consent: Lessons from Two Canadian
}

\section{Cases}

\author{
Martin Papillon \\ Université de Montréal, Montréal, Canada \\ martin.papillon@umontreal.ca \\ Thierry Rodon \\ Université Laval, Québec, Canada \\ thierry.rodon@ulaval.ca
}

\begin{abstract}
While it is increasingly recognised as a core element of the emerging international Indigenous rights regime, the implementation of the principle of free, prior and informed consent (FPIC) remains contested. As the comparative literature shows, if and how FPIC is implemented depend both on the institutional context and on the agency of actors involved. Faced with deep power asymmetries and strong institutional resistance to their understanding of FPIC as a decision-making right, a number of Indigenous groups in Canada have taken advantage of the uncertain legal context to unilaterally operationalise FPIC through the development of their own decisionmaking mechanisms. Building on two case studies, a mining policy adopted by the Cree Nation of James Bay and a community-driven impact assessment process established by the Squamish Nation, this article argues Indigenous-driven mechanisms can be powerful instruments to shape how FPIC is defined and translated in practice.
\end{abstract}

\section{Keywords}

Indigenous peoples - Canada - free, prior and informed consent (FPIC) - UNDRIP norm translation - community-driven impact assessment

(C) MARTIN PAPILLON AND THIERRY RODON, 2019 DOI:10.1163/15718115-02702009

This is an open access article distributed under the terms of the CC-BY 4.o License. 


\section{Introduction}

While it is increasingly recognised as a core element of the emerging international Indigenous rights regime, the principle of free, prior and informed consent (FPIC) remains a contested norm. Its legal interpretation and political translation by state institutions continue to be inconsistent and highly contingent. Comparative analyses of FPIC implementation underscore variations in the degree of state compliance, but also significant differences and disagreements as to the very meaning, scope and practical implications of the norm. ${ }^{1}$ Indigenous peoples themselves often challenge the Western-centric approach to their participatory rights that permeates debates at the national and international levels. ${ }^{2}$

Canada is no exception in this respect. As elsewhere, the debate tends to be polarised between an interpretation of FPIC as an Indigenous veto or as a state-centred procedural obligation to consult in order to seek, but not necessarily obtain, Indigenous consent when resource development projects may affect their rights. ${ }^{3}$ Little attention is given to Indigenous views on what consent means and how it should translate in practice.

1 C.M. Doyle, Indigenous Peoples, Title to Territory, Rights and Resources: The Transformative Role of Free Prior and Informed Consent (Routledge, New York, 2015); A. Tomaselli, 'The Right to Political Participation of Indigenous Peoples: A Holistic Approach', 24:4 International Journal on Minority and Group Rights (2017) pp. 390-427 DOI: 10.1163/15718115-02404006; J. Tockman, 'Eliding Consent in Extractivist States: Bolivia, Canada, and the UN Declaration on the Rights of Indigenous Peoples', 22:3 The International Journal of Human Rights (2018) pp. 325349 DOI: 10.1080/13642987.2017.1383241; A. Schilling-Vacaflor, 'Who Controls the Territory and the Resources? Free, Prior and Informed Consent (FPIC) as a Contested Human Rights Practice in Bolivia', 38:5 Human Rights Quarterly (2017) pp. 1058-1074; E. Leifsen, M.-T. Gustafsson, M.A. Guzmán-Gallegos and A. Schilling-Vacaflor, 'New Mechanisms of Participation in Extractive Governance: Between Technologies of Governance and Resistance Work', 38:5 Third World Quarterly (2017) pp. 1043-1057 DoI: 10.1080/01436597.2017.1302329; L.B. Fontana and J. Grugel, 'The Politics of Indigenous Participation Through 'Free Prior Informed Consent': Reflections from the Bolivian Case', 77 World Development (2016) pp. 249-261 Dor: 10.1016/j. worlddev.2015.08.023; T.G. Falleti and T.N. Riofrancos, 'Endogenous Participation: Strengthening Prior Consultation in Extractive Economies', 70:1 World Politics (2017) pp. 86-121.

2 See for example the various contributions to J. Borrows, L. Chartrand, O. Fitzgerald and R. Schwartz (eds.), Braiding Legal Orders. Implementing the United Nations Declaration on the Rights of Indigenous Peoples (Centre for International Governance Innovation, Waterloo (Ontario), 2019).

3 K.S. Coates and B. Flavel, Understanding FPIC. From Assertion and Assumption on FPIC to a New Model for Indigenous Engagement on Resource Development (MacdonaldLaurier Institute, Ottawa, 2016); M. Papillon and T. Rodon, 'Indigenous Consent and Natural Resource Extraction: Foundations for a Made-in-Canada Approach', Choice (2017), 
Faced with strong resistance to their own understanding of FPIC, a number of Indigenous groups in Canada have chosen to challenge the legitimacy of state-driven norms and processes. Instead, they seek to operationalise FPIC through the development of their own decision-making mechanisms, often in parallel to state-sponsored regulatory processes. They do so through the development of community-driven impact assessment for example, ${ }^{4}$ or through the negotiation of protocols and agreements with project proponents, under which the latter recognise Indigenous ways of expressing consent as a precondition for a project to proceed. ${ }^{5}$

This article discusses the transformative potential of these Indigenousdriven mechanisms for implementing FPIC. To do so, we document two examples of such innovative practices: the mining policy adopted by the Cree Nation of James Bay in their traditional territory of Eeyou Istchee and the community-driven impact assessment process established by the Squamish Nation (Sḱwxwúzmesh Úxwumixw) over concerns with a liquefied natural gas plant. These two cases illustrate different strategies Indigenous peoples can use to operationalise FPIC, depending on the legal, institutional and political context they face.

The James Bay Cree are signatories to the 1975 James Bay and Northern Quebec Agreement (JBNQA), a constitutionally protected land claims agreement under which they are guaranteed some level of participation in decisionmaking over land and resources management, but no right of veto or consent.

https://irpp.org/research-studies/insight-no16/; Hon. F. Iacobucci, J. Terry, V. Helbronner, M. Fortier and R. Lax, Free, Prior and Informed Consent in Canada: Towards a New Relationship with Indigenous Peoples (Torys LLP, Toronto, 2016); D. Newman, Political Rhetoric Meets Legal Reality. How to Move Forward on Free, Prior and Informed Consent in Canada (MacdonaldLaurier Institute, Ottawa, 2017); Tockman, supra note 2; D. Leydet, 'The Power to Consent: Indigenous Peoples, States, and Development Projects', 69:3 University of Toronto Law Journal (2019) pp. 371-403, DOI: 10.3138/utlj.2018-0o68.

4 G. Gibson, D. Hoogeveen and A. MacDonald, Impact Assessment in the Arctic: Emerging Practices of Indigenous-Led Review, Firelight Group and Gwich'in Council International (2018); C. O'Faircheallaigh, 'Shaping Projects, Shaping Impacts: Community-Controlled Impact Assessments and Negotiated Agreements', 38:5 Third World Quarterly (2017) pp. 1181-1197 Dor: 0.1080/01436597.2017.1279539.

5 C. O'Faircheallaigh, Negotiations in the Indigenous World: Aboriginal Peoples and the Extractive Industry in Australia and Canada (Routledge, New York, 2016); M. Papillon and T. Rodon, 'Proponent-Indigenous Agreements and the Implementation of the Right to Free, Prior, and Informed Consent in Canada', 62 Environmental Impact Assessment Review (2017) pp. 216-224 DOI: 10.1016/j.eiar.2016.o6.oog; M. Low, Practices of Sovereignty: Negotiated Agreements, Jurisdiction, and Well-Being for Heiltsuk Nation (Doctoral dissertation, University of British Columbia, 2018) DOI: 10.14288/1.0375642. 
Despite the limitations of the JBNQA, the Cree have used their institutional capacity to develop their own mining policy, under which they establish criteria for expressing their consent to projects and make such approval conditional on the negotiation of agreements with the project proponent. Our second case concerns the Squamish Nation, whose traditional territory sits on the northern edge of the city of Vancouver, in British Columbia. Unlike the Cree, the Squamish have not negotiated a land claims agreement, but they were able to take advantage of the legal uncertainty resulting from their unsettled title claim to develop their own FPIC mechanism, this time a communitybased impact assessment that was supported by the project proponent.

This study shows that under the right circumstances, Indigenous peoples can have significant agency in shaping how FPIC is interpreted and implemented. By unilaterally defining a process through which they express their consent, the James Bay Cree and Squamish Nation succeeded in reframing FPIC from a procedural duty of the state, under which their role is limited to being consulted on the impact of a project, to a matter of Indigenous jurisdiction over the project itself. In doing so, they also shifted the institutional site for operationalising F PIC from a state-driven to a community-driven process. They were able, in other words, to redefine both the meaning of FPIC and who decides how it is implemented in practice.

This strategy of norm translation through the development of communityled processes is not unique to Indigenous peoples in Canada. ${ }^{6}$ We suggest, however, that it is particularly conducive to transformative politics in the Canadian context, where FPIC does benefit from a certain level of recognition as a legitimate norm in public discourse, yet its interpretation remains debated and its implementation incomplete. While this ambiguity is often criticised, it also paradoxically creates an opening for Indigenous agency in shaping how the norm is translated in practice. We conclude with some reflections on the potential and limits of Indigenous-driven processes in light of the deep power asymmetries most Indigenous nations face when mobilising for FPIC implementation.

6 Doyle, supra note 1; R.K. Larsen, 'Impact Assessment and Indigenous Self-Determination: A Scalar Framework of Participation Options', 36:3 Impact Assessment and Project Appraisal (2018) pp. 208-219 DoI: 10.1080/14615517.2017.1390874; R. Lawrence and R.K. Larsen. 'The Politics of Planning: Assessing the Impacts of Mining on Sami Lands', 38:5 Third World Quarterly (2017) pp. 1164-1180 DOI: 10.1080/01436597.2016.1257909; O'Faircheallaigh, supra note 4; Leifsen et al., supra note 2; C.F. Fredericks, 'Operationalizing Free, Prior and Informed Consent', 80:2 Albany Law Review (2017) pp. 429-482. 
As Risse and Sikkink suggest in their ground-breaking comparative analysis of international human rights compliance, the translation of international norms into national frameworks is a social process. ${ }^{7}$ It is driven by interactions between state and non-state actors, who mobilise norms through various representation strategies at the national and international levels. In the absence of a basic shared understanding of what a norm actually entails, this translation process becomes more challenging. Conflicts over norm interpretation can hinder its institutionalisation and leave it subject to power politics. ${ }^{8}$ This is arguably the case for FPIC. Despite its broad recognition in international circles, FPIC remains a contested norm, both in terms of its substance and its operationalisation. ${ }^{9}$

By far the most debated dimension of FPIC has to do with its implications for decision-making in land resource development. Indigenous peoples consistently approach FPIC as an extension of their right to self-determination. ${ }^{10}$ The capacity to consent (or not) to an activity on their traditional land stems from their authority as self-governing polities free to determine their future, and by extension that of their land. FPIC, in other words, implies a jurisdictional capacity to make decisions, either unilaterally or in collaboration with competent state authorities. ${ }^{11}$ States and private corporations, by contrast, are reluctant to endorse a version of FPIC that could imply an Indigenous veto on

T. Risse and K. Sikkink, 'The Socialization of International Human Rights Norms into Domestic Practices: Introduction', in K. Sikkink, S. C. Ropp, and T. Risse (eds.), The Power of Human Rights: International Norms and Domestic Change (Cambridge University Press, Cambridge, 1999) pp. 1-38.

L.B. Fontana and J. Grugel, 'Deviant and Over-Compliant: The Domestic Politics of Child Labor in Bolivia and Argentina', 39:3 Human Rights Quarterly (2017) pp. 631-656.

M. Barelli, 'Free, Prior and Informed Consent in the Aftermath of the UN Declaration on the Rights of Indigenous Peoples: Developments and Challenges Ahead', 16:1 The International Journal of Human Rights (2012) pp. 1-24; P. Hanna and F. Vanclay, 'Human Rights, Indigenous Peoples and the Concept of Free, Prior and Informed Consent', 31:2 Impact Assessment and Project Appraisal (2013) pp. 146-157 Dor: 10.1080/14615517.2013.780373; A. Tomaselli, Indigenous Peoples and Their Right to Political Participation: International Law Standards and Their Application in Latin America (Nomos Verlag, Baden-Baden, 2016).

10 Doyle, supra note 1; J. Anaya, Human Rights Council, Report of the Special Rapporteur on the Rights of Indigenous Peoples: Extractive Industries and Indigenous Peoples, UN doc. A/HRC/24/41 (1 July 2013); Leydet, supra note 3 .

11 Assembly of First Nations, 'Submission on Free Prior and Informed Consent (FPIC) for the Expert Mechanism on the Rights of Indigenous Peoples', Expert Mechanism on 
extractive activities. ${ }^{12}$ Instead, governments tend to view FPIC as a mechanism to ensure the perspectives of Indigenous peoples are taken into consideration in the decision-making process, not as a process for sharing that decisionmaking authority. Faced with an uncertain legal environment, industry actors similarly seek Indigenous consent less as a mean to recognise their authority than in order to minimise the potential costs of protracted legal and political battles. Both states and industry actors therefore privilege a more diluted version of FPIC as a participatory right, which results in a procedural obligation to seek consent through what is often technical (and symbolic) consultation rather than as a substantive obligation to recognise the decision-making authority of Indigenous peoples and their representative institutions. ${ }^{13}$

The now abundant literature looking at FPIC interpretation in the international system, from courts to international organisations, NGOs and private corporations, reflects this debate over the scope of the norm. ${ }^{14}$ Comparative analyses looking at state compliance with FPIC underscore significant variations not only in the degree of institutionalisation of the norm, but also in its substantive interpretation and how it should be operationalised, with a strong tendency among states and industry actors to minimise its implications for existing decision-making processes. ${ }^{15}$

Indigenous peoples use different strategies to counter restrictive definitions of FPIC and promote their own understanding of the norm. Protests, public relations campaigns, international mobilisation, legal action and negotiations

the Rights of Indigenous Peoples (2018), <www.ohchr.org/Documents/Issues/IPeoples/ EMRIP/FPIC/AssemblyFirstNations_Canada.pdf>, visited on 29 March 2019.

12 Tockman, supra note 2; Doyle, supra note 1; Papillon and Rodon, supra note 3.

13 C.R. Garavito, 'Ethnicity.Gov: Global Governance, Indigenous Peoples, and the Right to Prior Consultation in Social Minefields', 18:1 Indiana Journal of Global Legal Studies (2010).

14 For insights into the international debates, see the report of Anaya, supra note 10, and see the recent report of the Expert Mechanism on the Rights of Indigenous Peoples by the Human Rights Council, Free, Prior and Informed Consent: A Human Rights-Based Approach, UN doc. A/HRC/39/62 (10-28 September 2018).

15 Fatelli and Riofrancos, supra note 2; Fontana and Grugel, supra note 2; Doyle, supra note 1; Tomaselli, supra note 2; Tockman, supra note 2; Papillon and Rodon, supra note 3; C. Allard, 'The Rationale for the Duty to Consult Indigenous Peoples: Comparative Reflections from Nordic and Canadian Legal Contexts', 9:1 Arctic Review on Law and Politics (2018) pp. 25-43; D. Szablowski, 'Operationalizing Free, Prior, and Informed Consent in the Extractive Industry Sector? Examining the Challenges of a Negotiated Model of Justice', 30:1-2 Canadian Journal of Development Studies / Revue Canadienne d'études Du Développement (2010) pp. 111-130 DOI: 10.1080/02255189.2010.9669284. 
are some of the most commonly used strategies. ${ }^{16}$ Faced with an uncertain and contested field, Indigenous peoples are also increasingly asserting their own vision of FPIC through their own mechanisms, to give FPIC meaning in practice. Building on case analyses, we suggest this process of norm definition though practice involves not only a framing strategy - in order to give meaning to the norm in public discourse - but also an institutional strategy, that is the act of creating a process for expressing free, prior and informed consent in a manner that corresponds to their understanding of the norm and their own governing procedures.

In reasserting control over the process through which they express their consent, Indigenous peoples challenge state-centred and instrumental views of FPIC and reaffirm their status as self-determining peoples with the capacity (and legitimacy) to make decisions over the future of their traditional lands. They also force governments and corporations engaged in the extractive sector to position themselves in relation to these Indigenous-driven mechanisms. They either accept them as a legitimate expression of FPIC or risk being accused of ignoring or rejecting FPIC altogether, therefore exposing themselves to legal and political challenges to the legitimacy of their own decision-making processes.

We further suggest that this process of norm appropriation is arguably more effective in contexts where FPIC benefits from a certain level of recognition as a legitimate norm in public discourse, yet its scope and operationalisation remain ambiguous. This lack of institutionalisation becomes an opportunity for Indigenous peoples to assert their own interpretation of the norm and establish their own mechanisms for operationalising it. As we show next, Canada is at such a critical juncture.

Indigenous Participatory Rights in Canada

Section 35 of the Constitution Act, 1982, recognises "the Aboriginal and treaty rights of Aboriginal peoples in Canada". It does not, however, define such rights. Courts have therefore played an important role in defining the scope

16 M. Papillon and T. Rodon, 'From Consultation to Consent: The Politics of Indigenous Participatory Rights in Canada', in A. Tomaselli and C. Wright (eds.), The Prior Consultation of Indigenous Peoples in Latin America. Inside the Implementation Gap (Routledge, forthcoming); A. Schilling-Vacaflor and R. Flemmer, 'Mobilising Free, Prior and Informed Consent (FPIC) from Below: A Typology of Indigenous Peoples' Agency', 27:2 International Journal on Minority and Group Rights (2020), this issue. 
and substance of Indigenous rights in Canada, including rights to land and participation in decision-making. The Supreme Court of Canada has established a Crown (the executive branch of federal and provincial governments) obligation to consult and, if necessary, accommodate Indigenous peoples before making a decision that could unduly affect the exercise of their rights recognised in the Canadian Constitution. ${ }^{17}$

In its jurisprudence on the duty to consult, the Court is very clear that it does not establish an Indigenous veto on government decision-making processes. ${ }^{18}$ It has nonetheless acknowledged that in some cases when the impact on Aboriginal rights is major, the Crown should consult with the objective of obtaining Indigenous consent before proceeding with a decision:

Where Aboriginal title is unproven, the Crown owes a procedural duty imposed by the honour of the Crown to consult and, if appropriate, accommodate the unproven Aboriginal interest ... By contrast, where title has been established, governments and others seeking to use the land must obtain the consent of the Aboriginal title holders. If the Aboriginal group does not consent to the use, the government's only recourse is to establish that the proposed incursion on the land is justified under s.35 of the Constitution Act, $1982 .{ }^{19}$

While it creates an obligation on governments to take Indigenous concerns into consideration in the regulatory process leading to the approval of projects that could impact their traditional lands, the doctrine of the duty to consult, accommodate and, under certain circumstances seek consent is not a recognition of Indigenous peoples' distinctive decision-making authority, let alone their sovereignty on the land. As the above suggests, it remains first and foremost a participatory right, derived from the Crown's duty to "act honorably" with its Indigenous subjects. ${ }^{20}$

The implementation of this jurisprudential doctrine has proven controversial and complex. The Court has thus far defined the modalities of the duty

17 See in particular Delgamuukw v. British Columbia [1997] 3 SCR 1010; Haida Nation v. British Columbia [2004] 3 SCR 511; Taku River Tlingit First Nation v. British Columbia [2004] 3 SCR 550; Rio Tinto Alcan Inc. v. Carrier Sekani Tribal Council [2010] SCC 43; Tsilhqot'in Nation v. British Columbia [2014] 2 SCR 256.

18 Haida Nation v. British Columbia, supra note 17, paras. 42 and 48 .

19 Tsilhqot'in Nation v. British Columbia, supra note 17, para. 76.

20 J. Borrows, 'The Durability of Terra Nullius: Tsilhqot'in Nation v. British Columbia', 48:3 UBC Law Review (2015) pp. 701-742. 
to consult on a case by case basis, using a spectrum approach under which the scope of the Crown's obligations depends on the nature of the project and its potential impact on Aboriginal rights. ${ }^{21}$ This approach has created a high degree of uncertainty as there are few criteria to clearly establish the level of required consultation and accommodation measures. The extension of the duty to consult in the territory of consent adds to this uncertainty. What is an adequate consultation in this context? Who should consult and when? If consent is required, how should it be expressed?

In the absence of legal clarity, it is not surprising that Canadian federal and provincial authorities have adopted an ambiguous position on FPIC. The Canadian government refused to endorse the UNDRIP when it was first adopted by the UN General Assembly in 2007, largely out of fear its dispositions concerning FPIC were not consistent with Canadian constitutional obligations and "could be interpreted as a veto" on economic development. ${ }^{22}$

Eager to break with the previous administration's confrontational approach to Indigenous peoples, the newly elected Liberal government announced in May 2016 that it was committed to the full implementation of the UNDRIP, without caveats. ${ }^{23}$ In a statement to the United Nations Permanent Forum on Indigenous Issues, the Minister of Indigenous Affairs took extra steps to note that this endorsement includes F PIC. The same statement nonetheless specifies that FPIC will be interpreted in continuity with Canada's existing regime of Indigenous rights. ${ }^{24}$

The federal government further clarified its position in 2017 in a policy statement titled Principles respecting the Government of Canada's relationship with Indigenous Peoples. ${ }^{25}$ The document addresses FPIC directly, stating that "meaningful engagement with Indigenous Peoples aims to secure their FPIC when Canada proposes to take actions which impact them and their rights on

21 D.G. Newman, Revisiting the Duty to Consult Aboriginal Peoples (Purich, Saskatoon, 2014).

22 J. McNee, 'Statement by Ambassador McNee to the General Assembly on the Declaration on the Rights of Indigenous Peoples', Nation Talk, 13 September 2007, < nationtalk.ca/ story/statement-by-ambassador-mcnee-to-the-general-assembly-on-the-declaration-onthe-rights-of-indigenous-peoples $>$, visited on 29 March 2019.

23 C. Bennett, 'Fully Adopting Undrip: Minister Bennett's Speech at the United Nations', Northern Public Affairs, 10 May 2016, <www.northernpublicaffairs.ca/index/fully-adoptingundrip-minister-bennetts-speech/>, visited on 29 March 2019.

24 Ibid.

25 Canada, Department of Justice, Principles Respecting the Government of Canada's Relationship with Indigenous Peoples, <justice.gc.ca/eng/csj-sjc/principles-principes.html>, visited on 29 March 2019. 
their lands, territories, and resources" (emphasis added). ${ }^{26}$ It adds that "to this end, the Government of Canada will look for opportunities to build processes and approaches aimed at securing consent, as well as creative and innovative mechanisms that will help build deeper collaboration, consensus, and new ways of working together" (emphasis added). ${ }^{27}$

The government therefore agrees that existing mechanisms for engaging Indigenous Peoples may be insufficient. At the same time, the wording of the statement suggests obtaining FPIC is interpreted as an aspirational goal rather than as a firm obligation. New processes should be "aimed at securing" consent rather than simply establishing consent.

Canadian provinces, which have considerable jurisdictional autonomy on land and resources management, have also been careful in statements concerning the UNDRIP and FPIC. While some Provinces have endorsed the UNDRIP in policy statements, few have taken concrete steps to establish a policy or legislative framework for its implementation. ${ }^{28}$

This legal and political ambiguity creates a high degree of uncertainty over resource extraction projects and the process through which these projects should be approved. Indigenous peoples are regularly challenging existing consultation processes as inadequate and inconsistent with both Canada's constitutional obligations and its international commitments under the UNDRIP. When a hydroelectric dam in British Columbia was approved over clearly expressed opposition from affected Indigenous communities, opponents called it a "profound betrayal of the solemn commitments undertaken when Canada ... endorsed the UN Declaration on the Rights of Indigenous Peoples". 29

Indigenous communities across Canada are also engaged in a legal and political struggle over oil and gas pipelines. Conflicts surrounding the Trans Mountain extension pipeline, which is expected to carry bitumen oil from Alberta to open waters in the Vancouver area, gathered much media attention

$26 \quad$ Ibid.

27 Ibid.

28 One exception in this respect is British Columbia, where the government has announced its intention to introduce legislation on the UNDRIP. See V. Palmer, 'B.C. Makes Ambitious Commitment to UNDRIP in Throne Speech', Vancouver Sun, 13 February 2019, < vancouversun.com/opinion/columnists/vaughn-palmer-province-makes-ambitious-commitmentto-undrip >, visited on 29 March 2019.

29 Assembly of First Nations, 'AFN National Chief Calls for Free, Prior and Informed Consent in Site C Dam Hydro Project', News and Media, 18 December 2014, </www.afn.ca/en/ news-media/latest-news/afn-nation-al-chief-calls-for-free-prior-and-informed-consent -in-site-c >, visited on 29 March 2019. 
when a group of Indigenous nations successfully challenged the federal process for approving the pipeline at the Federal Court of Appeal. ${ }^{30}$

Indigenous peoples are not alone in seeking clarity as to the interpretation and implementation of consultation and consent rules. Conflicts over interpretation of Indigenous rights and the duty to consult are proving costly for the resource extraction sector. ${ }^{31}$ Faced with Indigenous opposition, some project proponents have simply bailed out of their initial investment or threatened to do so as a result of the uncertain legal and political climate..$^{32}$

In the absence of clearly defined rules, the resource extraction sector has developed its own mechanisms for establishing legal clarity and minimise the risks of political instability surrounding their projects. One key mechanism that has emerged in recent years is the negotiation of private agreements directly with Indigenous communities to seek their support for a project in exchange for some benefits and impact mitigation measures. Impact and Benefit Agreements (IBAS) have become an effective mechanism for industry to circumvent the inadequacies of state-driven regulatory processes and secure Indigenous consent to resource extraction projects on their traditional lands. ${ }^{33}$

Whether IBAs are in themselves sufficient to establish free, prior and informed Indigenous consent to a project is a contentious question given the inherent asymmetry between the proponent and the Indigenous community in the negotiation process. ${ }^{34}$ Indigenous communities also sometimes sign IBAs less because they support the project than because they have little choice, knowing fully that the project is likely to go ahead even if they oppose it. ${ }^{35}$ The focus of negotiations is therefore less on the value of the project itself or its impacts, than on the content of the compensation package Indigenous communities can bargain in exchange for their consent. Under such circumstances,

3o The project's initial approval was overturned in light of what the Court considered a breach of the federal government's duty to consult. The Court ordered the federal government to engage in new, "enhanced" consultations with those Indigenous groups that were most affected by the project. See Tsleil-Waututh Nation v. Canada (Attorney General), 2018 FCA 153 (Can).

$31 \quad$ Coates and Flavell, supra note 3.

32 K. Bakx, 'Oil Export Pipelines: Will Canada Ever Build Another?', 2016, <www.cbc.ca/news/business/pipeline-canada-export-transmountain-keystoneenergyeast-1.3409134>, visited on 29 March 2019.

33 Papillon and Rodon, supra note 5; O'Faircheallaigh, supra note 5.

34 K.J. Caine and N. Krogman, 'Powerful or Just Plain Power-Full? A Power Analysis of Impact and Benefit Agreements in Canada's North', 23:1 Organization and Environment (2010) pp. $76-98$.

Papillon and Rodon, supra note 5 . 
it is hard to conclude this form of negotiated agreement truly constitutes free and informed consent.

FPIC in Canada is therefore at a critical juncture. It is increasingly recognised by governments and industry actors as a normative framework guiding their relations with Indigenous peoples. At the same time, its translation in practice remains uncertain and contested. Part of the challenge lies with the diverging interpretation of FPIC that are mobilised by different actors. For governments, FPIC tends to be defined as a procedural obligation, a necessary step in ensuring the legality and the legitimacy of existing decision-making structures; it is not, as Indigenous peoples would like it, a way to share this decisionmaking authority. Industry actors also increasingly recognise the necessity of seeking Indigenous support for their projects, but they do so for strategic purposes, with an economic goal in mind.

In the absence of mutual agreement as to its normative foundation, meaning and scope, FPIC therefore remains a contested norm with weak institutional foundations. It is in part to fill this normative and institutional void that Indigenous communities and nations establish their own approach to FPIC. In doing so, they stake their claims in the battle over the meaning of FPIC and its operationalisation.

\section{4 \\ Indigenous-Driven fPIC Processes: Two Examples}

The Squamish Nation (Skwxwú7mesh Úxwumixw, SN) is part of the Coast Salish peoples, and encompasses nine communities stretching from North Vancouver to the northern area of Howe Sound with a total population of 3600 . In recent years, it has faced significant pressures from industrial projects, most notably pipeline terminals designed to facilitate the exporting of oil and gas to Asian markets.

The SN is one of the lead opponents to the controversial Trans Mountain pipeline extension project. It has joined a group of Indigenous nations, municipalities and environmental activists who have successfully challenged the constitutionality of the regulatory consultation process that led to the federal government's approval of the project.

While the SN has adopted a legal and political oppositional strategy in the context of the Trans Mountain pipeline proposal, it is not the only approach it has taken in asserting its right to decide on pipeline projects. At the same time as it was challenging the Trans Mountain project, the SN was also developing an entirely different approach to exercising FPIC for another pipeline terminal project. Woodfibre Natural Gas seeks to build a liquefied natural gas 
(LNG) processing and export facility in the heart of the traditional territory of the Squamish Nation. The facility is expected to operate for 25 years and have an annual processing and exporting capacity of 2.1 million metric tons of LNG. The project is also expected to create approximately 600 jobs during construction and 100 permanent jobs when operational. ${ }^{36}$

The project was subject to an environmental assessment process under both British Columbia's Environment Assessment Act and the Canadian Environmental Assessment Act. While federal and provincial authorities made their own independent decisions in authorising the project, the main assessment report was completed on behalf of both regulatory authorities by the British Columbia Environmental Assessment Office. ${ }^{37}$ In compliance with its constitutional obligations, the Environmental Assessment Office assessed the level of required Indigenous consultations based on a 'spectrum' of intensity, according to an assessment of the strength of Indigenous rights claims and the potential impact of the project. The Squamish Nation consultation requirements were considered at the 'deeper end' of the spectrum. ${ }^{38}$ However, the process remained strictly consultative and did not guarantee Squamish Nation concerns would be reflected in the decision to authorise the process. Most critically for the $\mathrm{SN}$, while the government-led IA process considered the environmental impacts of the project, it did not address its cumulative effects over time, especially its potential long-term impact on Indigenous rights. ${ }^{39}$

It is important to note at this point that while it was critical of existing federal and provincial impact assessment and consultation processes, the SN leadership did not reject the project outright. The nation was divided on its value, some fearing its impact on the salmon fisheries and others seeing it as an economic opportunity ${ }^{40}$ The Squamish Chiefs and Council therefore sought to assert its jurisdictional capacity to make a free and informed decision concerning the project, based on the SN's own concerns and interests. The SN was, in other words, seeking to assert its capacity to express FPIC in a manner that is consistent with its right to self-determination.

36 Woodfibre LNG, The Woodfibre LNG Project, <www.woodfibrelng.ca/the-project/aboutthe-project/>, visited on 29 March 2019.

37 British Columbia, Environmental Assessment Office, Woodfibre LNG Project Assessment Report, 19 August 2015, <projects.eao.gov.bc.ca/api/document/58869291eo36fbo105769o bc/fetch $>$, visited on 29 March 2019 .

38 Ibid., p. 265.

39 A.S. Bruce and E. Hume, The Squamish Nation Assessment Process: Getting to Consent (Ratcliff \& Co. LLP, Vancouver, 2015).

$40 \quad$ Interview notes with Aaron Bruce, October 2017. 
To do so, the Squamish Nation created its own impact assessment (IA) process, in order to make their own decision on the value of the project. The SN faced many hurdles in developing its own IA model. For one, as a Band under the federal Indian Act, the Squamish Nation Council does not have the authority, under Canadian law, to create its own enforceable IA process. The process therefore ran the risk of being purely symbolic unless it was recognised in some form or another by regulatory authorities and the project proponent. Secondly, the SN sought to establish a comprehensive, credible and legitimate IA process. From the outset, the goal was to develop an evidenced-based process so the community had as much information as possible to deliberate over the value, risks and benefits of the project prior to its approval. ${ }^{41}$ To do so required expertise and resources the community did not have.

Instead of engaging in a unilateral but largely symbolic process, the $\mathrm{SN}$ sought to convince the project proponent to support its community-driven impact assessment process. This, as it turned out, was key to its success. Not only did the project proponent agreed to collaborate and fund the process, it also committed in a legally binding private agreement to respect its outcome. ${ }^{42}$

The project proponent saw its interest in developing a joint process. In the absence of a treaty or another agreement to that effect, the Squamish Nation's rights to the land remain unsettled. Building on the Supreme Court reasoning in the previously cited Tsilhqot'in Nation v. British Columbia case, the Squamish Nation could potentially see their Aboriginal title recognised in court, which would lead to a stronger post-facto obligation to obtain their consent for the project. ${ }^{43}$ Under this uncertain legal context and facing a risk of significant delays and costs, engaging with the Squamish peoples was a way to limit externalities for Woodfibre Natural Gas. ${ }^{44}$

A Framework Agreement was signed between Woodfibre Natural Gas and the Squamish Nation on 24 July 2014. The agreement established the Squamish Process, which the parties agreed would be separate from the federal and provincial IA processes. The proponent agreed to fund the process and provide the $\mathrm{SN}$ with all requested technical information on the project. It also agreed to a confidentiality clause so that the information provided by both parties could not be used as evidence by the Crown to discharge its own duty to consult. The proponent finally agreed to consider the mitigation measures proposed

\footnotetext{
$41 \quad$ Ibid.

42 Woodfibre LNG, Letter concerning the Squamish Nation Environmental Conditions, British Columbia Environmental Office doc. No. 150728 Letter EAO S.13, 26 June 2015.

43 Tsilhqot'in Nation v. British Columbia, supra note 17.

44 Interview notes with Woodfibre Natural Gas official (anonymous), October 2017.
} 
by the SN and, most importantly, to respect the outcome of the process. ${ }^{45}$ For Woodfibre Natural Gas, the agreement created legal certainty. For the SN, it was a concrete way to exercise its authority on its traditional territories outside of existing governmental mechanisms.

While the proponent was closely involved in the SN IA process, its methodology and scope were defined by the community, through an engagement process driven by the Squamish Chiefs and Council. ${ }^{46}$ Instead of reproducing federal and provincial IA processes, the Squamish Process focused on issues of direct concern to the community: the impacts of the project on land and waters, issues of governance, transmission of culture and history, etc. Community engagement was at the heart of the IA process. Community meetings, focus groups and direct dialogue with individual members allowed for a strong internal deliberative process. At the end of the process, the $\mathrm{SN}$ had a list of 25 conditions and mitigation measures that were submitted to the proponent and the relevant government authorities as preconditions to the emission of a Squamish Certificate of Approval. All conditions were eventually accepted by the proponent. The Squamish Chiefs and Council formally endorsed the project and agreed to an Impact and Benefits Agreement in 2018.47

In order to maximise the impact of their community-driven process, the Squamish Nation also sought to have it recognised by federal and provincial authorities as a distinctive but binding process. Not surprisingly, both levels of government were reluctant to recognise the authority of the SN process. As a result, the Squamish Nation did not formally engage in the regulatory consultation process, insisting instead on a government to government process to decide on the value of the project and discuss its impact on their rights and title. ${ }^{48}$ While they were not successful at having their process formally recognised by the BC Environmental Assessment Office and its federal counterpart, in their written justification for approving the project, the provincial Ministers

\footnotetext{
45 Bruce and Hume, supra note 39.

46 Squamish Nation, Written Submission to the CEAA Review Expert Panel, 23 December 2016, <eareview-examenee.ca/wp-content/uploads/uploadedfiles/o1313275.pdf>, visited on 29 March 2019.

47 Squamish Nation, Squamish Nation Council Approves Agreements with Woodfibre LNG Project, 23 November 2018, <www.squamish.net/squamish-nation-council-approvesagreements-with-woodfibre-lng-project/>, visited on 29 March 2019.

48 Squamish Nation, Letter to Ministers Coleman and Polak Re. Woodfibre LNG Project Environmental Assessment, 14 August 2015, < projects.eao.gov.bc.ca/api/document/5886929ae o36fbo105769oco/fetch>, visited on 29 March 2019.
} 
responsible nonetheless explicitly refer to the Squamish Process and the project proponent's commitment to comply with its 25 conditions. ${ }^{49}$

In developing their own IA process, the Squamish Nation sought to force other actors to acknowledge its legitimacy and authority as a decision-making agent. While it was successful in establishing a binding agreement with the project proponent, it was less successful with federal and provincial authorities. It nonetheless created a precedent the Ministers responsible for authorising the project simply could not ignore. In doing so, it succeeded in defining FPIC on its own terms. As Chief Ian Campbell declared when the Squamish Nation finally approved the project:

The Squamish Process was set in motion to ensure our Aboriginal rights and title interests are protected ... We won't allow outsiders, whether they support the proposal or oppose it, to decide for us. It is our future - our decision to make. ${ }^{50}$

Our second example is the Cree Mining Policy. The Cree Nation of Quebec is composed of nine communities in Eeyou Istchee, the traditional Cree territory in the James Bay region, with a total population of 18,000 people. In 1975, the Cree signed Canada's first modern treaty, the James Bay and Northern Quebec Agreement. The JBNQA was an out of court settlement following legal proceedings engaged by the Cree and other Indigenous communities against the James Bay hydroelectric megaproject. In exchange for monetary compensation and a land regime that, among other things, protects Cree hunting and trapping rights, the Cree "ceded and released" all other rights they may have over the territory covered by the agreement, including a possible Aboriginal title. They therefore do not have the same legal leverage as the Squamish Nation in creating uncertainty over jurisdictional issues on their traditional lands. They do, however, have significant institutional resources and political clout.

Unlike more recent land claims agreements, the JBNQA did not create a self-government structure for the Cree. It nonetheless established a series of Cree-controlled local and regional administrative structures, which, following successive agreements with the provincial government in 2011 and the federal government in 2017 , were consolidated under the umbrella of a single entity, the Cree Nation Government (CNG). In addition to this powerful

\footnotetext{
49 British Columbia, Environmental Assessment Office, Reasons for the Ministers' Decision for the Woodfibre LNG Project, 26 October 2015, <projects.eao.gov.bc.ca/api/document/588 69299e036fbo105769obf/fetch>, visited on 29 March 2019. 
administrative structure, the Cree Nation has a powerful political arm in the Grand Council of the Crees of Eeyou Istchee (GCCEI), the corporate body that signed the JBNQA on behalf of the Cree. The CNG and the GCCEI have a common elected board and executive. ${ }^{51}$

The JBNQA does not provide for Cree consent on projects on their traditional lands outside of the immediate boundaries of the communities themselves. Instead, the GCCEI appoints half the members of the federal and provincial regional boards that were created under the JBNQA to evaluate the impact of projects in Eeyou Istchee. However, these IA boards only have recommendation power. The ultimate decision to authorise a project remains in the hands of the federal or provincial government, depending on the nature of the project. $^{52}$

In light of these limitations, the Cree have faced their share of nonconsensual decisions concerning resource extraction since the signing of the JBNQA in 1975. From forestry to hydroelectric projects, they have regularly made national and international headlines for their mobilisation and staunch affirmation of their right to say no to projects that could have a negative impact on their traditional lands. While the JBNQA provides only limited legal foundations to oppose these projects, it gave the GCCEI and the CNG significant political and financial resources, which were mobilised over the years against a number of projects. ${ }^{53}$

While political and legal mobilisations proved effective in asserting Cree opposition to some development projects, it remained essentially an oppositional strategy driven by power politics, coalition-building and the tireless work of a team of legal advisors well-versed in Aboriginal law. The Cree did not have clear principles or guidelines on the kind of project they were willing to accept and under what criteria they were willing to do so. The mining boom of the late 200os prompted the Cree to adopt their own mining policy in 2010. ${ }^{54}$ The policy clearly states that the Cree are "not in principle opposed to mining development on their traditional territory", but that mining projects need to respect the principles established in the policy. In his foreword to the policy,

$5^{1}$ Cree Nation Government, Cree Nation Government: Governance and Structure, <www. cngov.ca/governance-structure/>, visited on 29 March 2019.

52 T. Rodon, 'From Nouveau-Québec to Nunavik and Eeyou Istchee: The Political Economy of Northern Québec', 38 Northern Review (2015) pp. 93-112.

53 Jenson and M. Papillon, 'Challenging the Citizenship Regime: The James Bay Cree and Transnational Action', 28:2 Politics \& Society (2000) pp. 245-264.

54 CreeNation Government, CreeNationMining Policy, 2010-17, <www.cngov.ca/environment/ mining/>, visited on 29 March 2019. 
Cree Grand Chief Matthew Coon Come unequivocally states that Cree consent is required for projects in Eeyou Istchee:

It is clear in our policy that no mining development will occur within Eeyou Istchee unless there are agreements with our communities. Those agreements will need to address a wide range of social, economic and environmental concerns on the part of our communities. Through these agreements we will ensure that mining development is in keeping with our traditional approach to sustainable development. ${ }^{55}$

Unlike the Squamish Nation, who created its own IA process, the Cree opted to continue to rely on existing co-managed IA processes created under the JBNQA to inform their decision-making. However, like the Squamish Nation, they have made their support for a project conditional on the negotiation of an agreement with the project proponent. Cree consent is therefore tied to the negotiation of an IBA, but the decision to sign or not an IBA is subject to an internal deliberative process at the community and at the regional level.

The Cree Nation Mining Policy itself has no legal force under Canadian law. It is largely a symbolic policy designed to establish the principles and processes that should guide the expression of Cree consent. The strength of the Cree Nation policy lies elsewhere, in the mobilisation capacity of the GCCEI and in its capacity to influence project proponents and federal and provincial authorities. The goal of the policy is to create a process that establishes the jurisdiction of the Cree Nation, thereby forcing other actors to make a difficult choice: acknowledge the Cree process or face the consequences, which include costly legal challenges that can significantly delay a project and/or political mobilisations in the form of national and international public relations campaigns against the project.

The Cree policy was effective in the context of a gold mine project $190 \mathrm{~km}$ to the east of the community of Wemindji. In that case, both internal community consultations and public hearings organised through the regional co-management board were conducted. ${ }^{56}$ Satisfied with these processes, the Cree authorities notified the proponent that they were willing to negotiate an agreement, based on some of the conditions defined through the IA process.

\section{$55 \quad$ Ibid, p. 1.}

56 T.D. Monaghan, A.M. Hernandez and K. LeBlanc, 'Exploring the dynamic between the environmental and social impact assessment (ESIA) and impact benefit agreement (IBA) processes by demonstrating the benefits and limitations of each process as assessed through the lens of an environmental Cree communication strategy', presented at the IAIA 2016 conference, Aichi-Nagoya, Japan, 11-14 May 2016. 
The Opinagow Collaboration Agreement was signed in February 2011 with GoldCorp. The agreement clearly stipulates in section 1.12 that by signing this agreement, the Cree were exercising their capacity to consent to the project: "Within the scope of the rights of each Party and of Applicable Laws, the Cree Parties consent to the Eleonore Project in accordance with the terms of this Agreement".57

In this example, consent was codified through an IBA, but the latter was negotiated under conditions established by the community and only once the community accepted the project in principle. A second example, the Matoush uranium mine, located near the Cree community of Mistissini, illustrates how the Cree mining policy can also be mobilised as a foundation for refusing a project. This is a project that stirred controversy from the outset, with many Cree hunters expressing reluctance to see this type of mining on their ancestral land. ${ }^{58}$ The two co-managed IA reviews gave a positive recommendation to the project, but emphasised the absence of a clear "social license" as a caveat to its authorisation. ${ }^{59}$

This, of course, was not in itself enough to halt the project, but the Grand Council of the Crees of Eeyou Istchee added pressure on the proponent by refusing to engage in IBA negotiation, based on the lack of local consent. The Cree used their Mining Policy to challenge the legitimacy of the project, based on their own jurisdictional right to say yes or no. Faced with a potentially long and costly legal battle, the Government of Quebec sought to preserve its relationship with the Cree. It announced in 2013 a moratorium on uranium mining, putting an end to the project. While a number of considerations entered in the decision, the Minister underlined the lack of Cree support in a letter to the project proponent explaining its decision:

The absence of social acceptability on the part of the Cree community, the population directly affected by the Project, is obvious and determinative ... as far as we know, there is no agreement between the proponent

57 Grand Council of the Crees, Opinagow Collaboration Agreement, as amended, 8 May 2015, <s22.q4cdn.com/653477107/files/doc_downloads/portfolio_docs/eleonore/goldcorpopinagow-en-web.pdf $>$, visited on 29 March 2019.

58 S. Bourgeois, Comprendre la construction du moratoire administratif sur l'exploration/ l'exploitation uranifère: L'influence des coalitions allochtones et autochtones (Department of Political Science, Université Laval, Quebec, 2017).

59 J. Orkin, 'Consent and Consultation: Case Study of the Cree Nation's Stand against Uranium, presented at the Modern Treaty and Reconciliation Conference (Ottawa, November 2017), <landclaimscoalition.ca/pdf/BOıB-ConsentandConsultation-Orkin171114.pdf>, visited on 29 March 2019. 
and the Cree community of Mistissini. ... Under these circumstances, your Project has not obtained social acceptability and therefore does not accord sufficient importance to the principles enumerated in the Environmental Quality Act, particularly with regard to the protection of the social environment and the protection of Aboriginal peoples, their societies, their communities and their economy. ${ }^{60}$

This case illustrates how the institutionalisation of FPIC, through the Cree Nation Mining Policy, forced other actors to acknowledge Indigenous understanding of what consent means and how it should be expressed. In this case, as with the Squamish Process, it is the institutional gap between the principle of Indigenous consent and the relative absence of a clear mechanism to establish this consent that opened the door to the Cree appropriating the language of consent and creating their own approach to implementing it.

While FPIC is increasingly part of Canada's normative landscape, it is still a contested norm. Its meaning, scope and operationalisation are all debated in the political and legal arenas by actors who seek to establish their own vision of the norm and their own mechanisms to translate it in practice. Of course, this political process is not taking place in a vacuum. Settler colonial policy legacies and their underlying conception of Indigenous-state relations profoundly shape how FPIC is apprehended in the Canadian context. Jurisprudential interpretations of constitutionally protected Aboriginal and treaty rights also influence how governments, industry and Indigenous actors translate the norm in their own practices.

As elsewhere, the language of consultation and consent is also interpreted by Canadian governments and industry actors to limit the normative and practical implications of FPIC. ${ }^{61}$ By engaging in existing federal and provincial IA mechanisms, Indigenous peoples agree to an operationalisation of FPIC understood as a participatory right of consultation within decision-making

6o Québec, Ministère du Développement durable, Environnement et Lutte contre les changements climatiques, 'Développement de la filière uranifère : Le gouvernement annonce la réalisation d'études et confie au BAPE un mandat d'enquête et de consultation', Press Release, 28 March 2013, <www.environnement.gouv.qc.ca/infuseur/communique. asp?no=2383 $>$, visited on 29 March 2019 .

61 Shilling-Vacaflor, supra note 2; Fredericks, supra note 6; Szablowski, supra note 15 . 
structures they do not control. While IBAs create a process under which Indigenous consent is explicitly recognised by project proponents, they can also result in a truncated form of consent premised on a cost-benefit logic that does not necessarily reflect community concerns and ontological views of land and natural resources development. ${ }^{62}$

In light of this limited landscape, Indigenous peoples are asserting their own understanding of FPIC. Indigenous strategies to translate FPIC on their own terms can take various forms, but the development of community mechanisms for expressing consent (or lack thereof) can be a particularly potent approach for communities seeking agency in defining how FPIC should be operationalised. As the two examples discussed here show, through communitydriven strategies, Indigenous peoples can shift the 'site' for implementing F PIC from state-driven consultation and industry-driven IBAs to processes they control. In the absence of a clear legal framework or mutually agreed upon and institutionalised procedures to seek Indigenous consent, governments and corporations engaged in the extractive sector are forced to position themselves in relation to these alternative Indigenous-driven mechanisms. Both the project proponent and regulatory bodies at the federal and provincial levels were forced to acknowledge the legitimacy of the Squamish Process. Similarly, the Cree Nation Mining Policy served to establish a clear process through which the Cree could say yes or no to various projects.

By asserting control over the process through which they express their consent, the Cree and Squamish also clearly positioned FPIC as a matter of jurisdiction rather than as a right to participate in state-led decision-making, therefore reconnecting FPIC with its original formulation in the UNDRIP as an expression of Indigenous peoples' right to self-determination. The James Bay Cree have agreed to engage in regulatory public hearings, but they also conduct their own consultations and make their approval of mining projects conditional on the negotiation of an agreement with the proponent. In setting the criteria for such an agreement, they take ownership of the process rather than letting the proponents define it. The Squamish Nation chose a different route. The Squamish Chiefs decided to create their own impact assessment process in collaboration with the proponent. In doing so, they shifted from the position of being consulted in a decision-making process they did not control to actually making the decision themselves.

If this strategy of norm appropriation through community-driven processes can potentially shape how FPIC is implemented, it remains a political process and the success of these strategies ultimately depends on their recognition by 
third parties. While some Indigenous communities engage in unilateral norm appropriation in the absence of any dialogue with state and corporate actors, our two cases suggest a more effective way to shape FPIC implementation is to create processes that benefit from some level of recognition and legitimacy by third parties, through negotiated agreements or through power politics. The capacity to 'scale up' the internal process in order to give it legitimacy and meaning in the eyes of other actors is important. Comparisons with other successful and less successful examples of Indigenous-led processes could lead to possible explanations for when and how these strategies actually do scale up and are recognised by other parties.

For appropriation to be more than merely symbolic, it also requires significant institutional resources and capacity. The Cree Nation benefits from strong institutions resulting from the JBNQA and a long experience in developing their own corporate processes in land and environmental management. The Squamish Nation benefits from a complex legal context that creates powerful incentives for government and industry actors to collaborate with them. Smaller Indigenous communities may not have the same capacity to engage in the development of complex impact assessment and decision-making mechanisms. Again, a broader comparative analysis could shed some light on the potential and limits of different strategies for smaller or less resourceful communities. 